Author's Original Manuscript (AOM)/Preprint of an article published by Taylor \& Francis in Quarterly Review of Film and Video on May 14 2020, available online: https://doi.org/10.1080/10509208.2020.1764322

\title{
Unreliable Narrators for Troubled Times: The Menacing "Digitalisation of Subjectivity" in Black Mirror
}

Teresa Sorolla-Romero (corresponding author)

Communication Sciences Department, Universitat Jaume I, Castellón, Spain https://orcid.org/0000-0003-2768-4169

tsorolla@uji.es

José Antonio Palao-Errando

Communication Sciences Department, Universitat Jaume I, Castellón, Spain

Javier Marzal-Felici

Communication Sciences Department, Universitat Jaume I, Castellón, Spain

https://orcid.org/0000-0002-2462-1122

\section{Funding}

This work was supported by the Universitat Jaume I for the research project “Análisis de identidades en la era de la posverdad. Generación de contenidos audiovisuales para una Educomunicación crítica" under Grant code 18I390.01/1, and by the Ministerio de Ciencia, Innovación y Universidades del Gobierno de España for the research project "Participación ciudadana y medios de comunicación públicos. Análisis de experiencias de co-creación audiovisual" en España y en Europa under Grant code RTI2018-093649B-I00. 


\section{Unreliable Narrators for Troubled Times: The Menacing "Digitalisation of Subjectivity" in Black Mirror}

This article offers an examination of the television series Black Mirror (2011-) using a theoretical framework for studying post-classical narrative complexity. Its basic proposition is that narrative fracturing and misleading points of view are used in Black Mirror to offer a critique of the excessive confidence in digital technology and social networks as regulators of human subjectivity. While a mission historically attributed to science fiction is the exploration of a particular contemporary issue by expressing it in fiction form, Black Mirror offers an innovative twist on this objective by incorporating the narrative complexity of the mind-game film through the perspective of distorted subjectivities. In nearly every episode, the conflict that arises highlights the dangers inherent to the naturalisation of technological devices that virtually become appendages of the human body. Most episodes explore the negative consequences of the unrestrained use of new technologies to control memories, regulate personal relationships or reduce all human experience to data. The absence of any debate questioning their value results in a completely alienated society that feeds on the fictionalisation of politics and private life, in which individuals are incapable of distinguishing between reality and fiction, or even between what is happening outside and inside their own minds.

Keywords: Black Mirror; post-classical cinema; puzzle films; complex television; television fiction; film studies.

\section{Fragile worlds in mainstream cinema: an introduction to the phenomenon of the mind-game film}

At the end of the twentieth century and the dawn of the twenty-first (1), the screens of mainstream film theatres - and, by extension, the various screens of the digital devices that form part of everyday domestic life- became filled with amnesiac, schizophrenic, disoriented protagonists incapable of directing their own stories or taking responsibility for their past. These characters inhabit narratives offered to the spectator in fragmented form, often breaking with temporal linearity and requiring considerable effort to interpret. As a result, the kind of complexity that mainstream film and television have generally shied away from seems to have found a place in these narratives, resulting in popular films like The Sixth Sense (1999), Fight Club (1999), Memento (2000), The Others (2001), Eternal Sunshine of the Spotless Mind (2004), Black Swan (2010), Shutter Island (2010), and Inception (2010), or television series like Lost (2004-10), Fringe (2008-13), Flashforward (2009-10), and Black Mirror (2011-), the last of which is the focus of this study. 
Recent film theory has characterised this phenomenon as a feature of postclassical cinema(2) and has given it various names, including "puzzle films"1, "mindgame films", "complex television", "forking-path narratives"4, "modular narratives"5 and "multiple-draft-films". Although each of these concepts imbues the general phenomenon of complex narratives ${ }^{7}$ with different connotations, all of them involve a kind of reality crisis. In this article, we will analyse one of the cultural malaises underlying these fractured narratives and propose an explanation for this stretching of mainstream film and television conventions that has crossed boundaries between different national film industries and distribution circuits. In this sense, Elsaesser explains that "the tendency is not confined to Hollywood or North American directors. [...] 'mind-game' films are also being made in Germany, Denmark, Britain, Spain, South Korea, Hong Kong, and Japan." 8 As Jason Mittell ${ }^{9}$ has shown in his analysis of the increasingly broad, heterogeneous complexity of television series at the turn of century,

narratively complex television demands you pay attention to the window frames, asking you to reflect on how it provides partial access to the diegesis and how the panes of glass distort your vision of the unfolding action. ${ }^{10}$

This brand of complexity, which involves the spectator directly, can be found in both cinema and television and is identifiable today in series like Hannibal, River, Rellik, and Westworld.

Black Mirror, a series of self-contained episodes with no relation between their respective plotlines, is a good example of the phenomenon because the internal narrative of each episode reflects patterns similar to those of a cinematic narrative. Although it falls into Mittel's category of contemporary complex television, Black Mirror has certain unique qualities that need to be highlighted in order to understand how its narrative works. An analysis of these qualities will also help to identify how the series fits into the theoretical framework we will develop later. One of its most notable features is the fact that Black Mirror can be classified as an anthology series-one of the most successful

\footnotetext{
${ }^{1}$ Buckland, Hollywood Puzzle Films; Buckland, Puzzle Films: Complex Storytelling in Contemporary Cinema.

${ }^{2}$ Elsaesser, "The Mind-Game Film”; Elsaesser, "Los Actos Tienen Consecuencias. Lógicas Del Mind-Game Film En La Trilogía de Los Ángeles de David Lynch.”

${ }^{3}$ Mittell, Complex TV : The Poetics of Contemporary Television Storytelling.

${ }^{4}$ Bordwell, "Film Futures."

${ }^{5}$ Cameron, Modular Narratives in Contemporary Cinema.

${ }^{6}$ Branigan, "Nearly True : Plots , Forking Forking Interpretations."

${ }^{7}$ Simons, "Complex Narratives," 2008.

${ }^{8}$ Elsaesser, "The Mind-Game Film," 15.

${ }^{9}$ Mittell, "Narrative Complexity in Contemporary American Television"; Mittell, "Sites of Participation: Wiki Fandom and the Case of Lostpedia"; Mittell, Complex TV : The Poetics of Contemporary Television Storytelling.

${ }^{10}$ Mittell, "Narrative Complexity in Contemporary American Television," 38.
} 
types of programming in the first decade of television history ${ }^{11}$ - since each episode presents a different story in a new location, with a different set of characters. Yet despite the discrete nature of the episodes, there are strong aesthetic and thematic connections (especially between the episodes of the first and second season, on one hand, and the third and fourth ones, on the other) that foster the impression that all these stories belong to the same dystopian future. In addition, in the later seasons there are characters who make references to places or motifs featured in other episodes. Through this strategy, the imaginary universe of Black Mirror seems more cohesive. The thematic core that most clearly links all the episodes of the series is the aggressiveness and moral unscrupulousness of a society that allows experimentation with the bodies, minds and (once again) subjectivities of consumers. Charlie Brooker, the creator of the series, openly acknowledges the influence of the classic science fiction series The Twilight Zone on Black Mirror. As "the series that marked the maturation of science fiction television as a genre," 12 The Twilight Zone combined the anthology drama format with science fiction's interest in interrogating the present through the depiction of imagined worlds in some distant future that can serve as metaphors for contemporary society's fears and taboos. The influence of The Twilight Zone on Black Mirror is evident in the fact that both series portray worlds

where ideas are suppressed, where knowledge is devalued, where people do not read, where communication itself is problematic, is doomed. [...] often in settings of quasi-Orwellian, fascistic dystopias where messages of conformity and the modes of those messages become equally significant. ${ }^{13}$

Decades later, in Black Mirror, this situation is embodied in exquisite, chic, minimalist devices used as widely as the smartphone is in our society. In nearly every episode, the conflict that arises highlights the dangers inherent to the naturalisation of such devices, which virtually become appendages of the human body. The absence of any debate questioning their value is contextualised in a completely alienated society sustained on the fictionalisation of politics and private life (3), in what could be described as a kind of post-life after death. This feeling, which pervades all the episodes, concerns familiar technologies — "promoted around desires for freedom, consumer choice, and convenience"14_quite similar to the devices commonly used to access the vast range of content available on the Internet. According Lisa Parks, all this reflects a "distinct culture organized around middle-class fantasies of transport, personal freedom, and

${ }^{11}$ Tellote, "Lost in Space: Television as Science Fiction Icon."

${ }^{12}$ Brooker, Science Fiction Television: A History, 6.

${ }^{13}$ Hill, "Anthology Drama: Mapping The Twilight Zone's Cultural and Mythological Terrain," 122.

${ }^{14}$ Tryon, "TV Time Lords: Fan Cultures, Narrative Complexity, and the Future of Science Fiction Television," 137. 
citizenship." ${ }^{15}$ With the change of its production and distribution from Channel 4 (UK) to Netflix, the series as a whole takes a turn towards gentler universes and critiques in terms both of plot and of aesthetics, with a clear predominance of pastel colours and characterisations that offer a nostalgic depiction of the fashions of the 1980s and 1990s, in contrast with the colder, darker mise-en-scènes predominant in the first and second seasons. The episodes "Nosedive" (\#3x01), "USS Callister" (\#4x01), "Hang the DJ" (\#4x04), and (to some extent) "San Junipero" (\#3x01) are examples of this change. In terms of plots, in its first seasons the narratives expressed a radically pessimistic point of view, proposing some disturbing connections between the spheres of politics, justice and the media, while the later seasons seem to adopt a lighter approach. For example, while in the first season the pressure to portray oneself as successful on social media leads to a suicide attempt (\#1x02, "Fifteen Million Merits"), the tone in which this same issue is addressed later (\# 3x01, "Nosedive", and \# 4x04, "Hang the DJ") seems less tragic and, in the latter case, is even given a happy ending. Despite this, the idea of new technologies as a source of anxiety, especially in relation to the protagonists' social life and closest relationships, remains a key theme throughout the series, especially evident in episodes such as "Shut Up and Dance" (\#3x03) or "Hated in the Nation" (\#3x06).

But how do these specific features of Black Mirror fit into descriptions of the contemporary trend of complex narratives? In his definition of the puzzle film, Warren Buckland offers a list of features that includes "fragmented spatiotemporal reality, time loops, a blurring of the boundaries between different levels of reality, unstable characters with split identities or memory loss, multiple, labyrinthine plots, unreliable narrators, and overt coincidences." 16 Particularly significant for our study is the importance that Thomas Elsaesser, who coined the term "mind-game film", attributes to the representation of subjective perception in these kinds of films and TV series. Eleftheria Thanouli attributes the "subjective realism"17 of post-classical cinema to the development of imaging technologies. These cover a wide range of devices with recording capacities (from smartphones to new cameras such as GoPro, used both by amateur and professional users), as well as post-production effects. An important aspect of these new imaging technologies, especially in terms of shared personal experiences, is the omnipresent option of disseminating the images they capture on social media, perhaps best epitomized in Black Mirror in the episode "Nosedive" (\#3x01). As Thanouli points out, this option facilitates a kind of "dramatisation" of the subject's experience (4). Mind-game films go further, presenting a world in which "there is no perceptible difference either in the visual register or in terms of verisimilitude, between real and imagined, real and simulated, real and manipulated." 18 To understand how Black Mirror may fit into the theoretical framework of the mind-game film, it is important to highlight the fact that the uncertainty

\footnotetext{
${ }^{15}$ Parks, "Flexible Microcasting: Gender, Generation, and Television-Internet Convergence," 137.

${ }^{16}$ Buckland, Hollywood Puzzle Films, 5.

${ }^{17}$ Thanouli, Post-Classical Cinema : An International Poetics of Film Narration, 50.

${ }^{18}$ Elsaesser, "The Mind-Game Film," 18.
} 
and distortions experienced by the characters in the series affect the enunciative level of the story, giving rise to complex narratives that anchor the spectator to the troubled subjectivity of a character who is a victim of a manipulation of consciousness and memory (sometimes self-provoked). In this way, the interference of technology in the most intimate subjectivity of the protagonists results in distortions to their original memories, their conception of the present and their own identity, the veracity of which is constantly called into question. This premise lies at the core of episodes like "White Bear" (\#2x02), "Playtest" (\#3x02), "San Junipero" (\#3x04) or "Men Against Fire" (\#3x05). In "White Bear", which will be explored in more detail later in the paper, what seem to be the flashbacks of the amnesiac protagonist lead us to believe that she had a family that somehow has been taken away from her. However, in the end, she is revealed to be an accomplice in the murder of the little girl that we mistook to be her daughter.

The fact that spectators have to reorganise the temporal order or question the ontological contradictions of what is presented as reality prevents them from embarking freely on the "immobile journey"19 commonly associated with mainstream cinema. Instead, these narratives demand a "loss of calm contemplation" 20 , and an active involvement in the interpretation of the story, which reveals itself to be inconsistent. In this way, the editing acts as a "persistent reminder of the abyss of darkness that subtends cinema." 21

\section{The potential influence of new technologies on fractured narratives}

A number of mind-game films are marked by a suspicious undertone that appears to identify digital technologies as the cause of the perceptual disorders of their protagonists and, therefore, as responsible for the narrative confusion or non-linearity of these films. This is the case, for example, of Inception, Paycheck (2003) and Eternal Sunshine of the Spotless Mind. The relationship between the digitalisation of the image and the complex narrative is multifaceted and may be approached from various angles.

The contemporary spectator has access to an increasing diversification of audiovisual languages. As the film industry loses its hegemony over mass culture entertainment - due to competition from television, of course, but also from video games and highly heterogeneous online content - its language has begun to hybridise with those of the new media. ${ }^{22}$ One of the perspectives explored in studies of post-classical fractured narratives posits that the technological influence of new forms of media consumption is encouraging narrative experimentation. Such experimentation would include the adoption of discursive resources characteristic of the new media, such as multiple plotlines or the representation of subjective points of view. In relation to this study, one of the most

\footnotetext{
${ }^{19}$ Burch, El Tragaluz Del Infinito : Contribución a La Geneaología Del Lenguaje Cinematográfico.

${ }^{20}$ Michaud, Aby Warburg and the Image in Motion, 84.

${ }^{21}$ Doane, The Emergence of Cinematic Time : Modernity, Contingency, the Archive, 275-276

${ }^{22}$ Lister, New Media : A Critical Introduction.
} 
interesting features of both these resources is that they constantly present apparently insoluble contradictions that undermine the communicative effectiveness of the narration.

In this respect, Lev Manovich ${ }^{23}$ suggests that the advent of digital cinema raises the question of whether the post-modern boom in non-linearity may be conditioned by the sequential access and malleability of the kinds of narratives permitted by digitalisation. This would represent an attempt to approximate the interactivity of digital media, in a kind of "Cinema 3.0". ${ }^{24}$ Another scholar who takes this position is Allan Cameron, as noted by Buckland in the introduction to his seminal anthology Puzzle Films. He summarises Cameron's position as follows:

complex storytelling [...] responds to technological developments (here, narrative is not automatically and passively manipulated by an external cause; instead, it reacts to an external cause). In addition, [such storytelling] [...] is part of a wider epistemological shift in rethinking identity, reality and especially time. ${ }^{25}$

Rather more directly, Christine Bolewski asserts that complex narratives "can be seen as an influence of digital nonlinear computer editing, which encourages experimentation with film structure." 26 This is because "new media have proposed a different set of possibilities for media communication and textuality." 27 In this sense, Sean Cubitt interprets the film Source Code as a "rendition" of digital time. ${ }^{28}$ In fact, the same film is analysed by Buckland ${ }^{29}$ to demonstrate the influence of video-game logic on post-classical cinema.(5) However, our interest here is not the fractured narrative resulting from the direct influence of other media, but the intersection between that potential influence and the spread of digital culture as a recurring theme in the story-lines of Black Mirror. In other words, we are interested in the meeting point between the particular narrative influenced by the new media and technologies and how its plot explores concerns about these very same technologies.

\section{Contemporary uncertainty and the loss of personal subjectivity}

We noted above that a kind of reality crisis pervades post-classical fractured narratives, and that one of their constants is the portrayal of individuals who are incapable of distinguishing between what is happening outside and inside their own minds.

\footnotetext{
${ }^{23}$ Manovich, El Lenguaje de Los Nuevos Medios de Comunicación : La Imagen En La Era Digital.

${ }^{24}$ Daly, "Cinema 3.0: The Interactive-Image," 81.

${ }^{25}$ Buckland, Hollywood Puzzle Films, 3-4.

${ }^{26}$ Bolewski, "Nonlinear Narratives: Crossing Borders between Contemporary Film, Art and Digital Media Practice," 241.

${ }^{27}$ Young, The Cinema Dreams Its Rivals : Media Fantasy Films from Radio to the Internet, 12.

${ }^{28}$ Cubitt, The Cinema Effect.

${ }^{29}$ Buckland, Hollywood Puzzle Films.
} 
A crisis of confidence in the State, the law, love, science, technology, or the family is a central theme that shapes the plots of mind-game films and complex television series. A prominent aspect of this crisis is a fear of the loss of the parameters that govern reality, as if narrative complexity were a symptom of a collective instability experienced in reaction against a sense of a change of era felt in different sectors of Western society. One factor that some scholars believe fosters this sense of alienation is the existence of a "dislocated international economy", ${ }^{30}$ reflected in the financial crisis of 2008. The resulting "meta-reality", overlapping with the physical world, largely determines how society functions and even seems beyond the control of institutions like the International Monetary Fund or the World Bank. ${ }^{31}$ Another factor affecting the destabilisation of our conception of space and time is the paradigm shift in science towards quantum physics, ${ }^{32}$ with its promotion of hypotheses about parallel universes or time travel which, like a new "Copernican turn", calls into question the correspondence of human physiological perception with the physicality of the world. The intertwining between narrative complexity and these themes, particularly attractive to the science fiction genre, can be observed in series such as Lost or Fringe and films like Donnie Darko (2001), Primer (2004), Interstellar (2014), or Arrival (2016).

The irrepressible growth of digital technology as a foundation for the organisation of our world has also given rise to obsessions of particular eras, such as the panic inspired by the Y2K bug, which exemplifies our fear of the collapse of that parallel universe composed of digits. Zygmunt Bauman theorises about such contemporary fears, suggesting that civilization "always stays but one shock away from inferno." 33 Among the contemporary fears mentioned by Bauman is a paranoid tendency that leads the modern individual to distrust everyone and to feel like the victim of an ongoing conspiracy, which, according to Kilbourn, has developed into a terror in recent years: "this panoptic paranoia in the experience of viewing: the fear of being seen and/or of being able to see, all the time, where one is both object and subject of the gaze." 34

Mind-game films promote the idea that the image overload characteristic of digital culture does not guarantee a stable identity, but quite the opposite. The consequences of this have been studied in relation to reality TV shows such as Catfish (Lovelock 2016). Despite the value of photography as a "prosthetic memory", ${ }^{35}$ the image is repeatedly revealed to be misleading when protagonists turn to it to make sense of their past. Paradoxically, the outcome of the immense archive of images of the information age is amnesia. As Kilbourn explains, while "prosthetic memory technology, from the archive

\footnotetext{
${ }^{30}$ Zavala, "Para Analizar La Metaficción En Cine," 86.

${ }^{31}$ Català Domènech, "El Tiempo Visible," 38.

${ }^{32}$ Dzialo, "'Frustrated Time' Narration: The Screenplays of Charlie Kaufman."

${ }^{33}$ Bauman, Miedo Líquido : La Sociedad Contemporánea y Sus Temores, 17.

${ }^{34}$ Kilbourn, Cinema, Memory, Modernity: The Representation of Memory from the Art Film to Transnational Cinema, 103.

${ }^{35}$ Lury, Prosthetic Culture: Photography, Memory and Identity; Sutton, Photography Cinema, Memory: The Crystal Image of Time.
} 
to the personal handheld device, is itself incapable of forgetting", ${ }^{36}$ these databanks cannot sustain the story of the amnesiac subject.

This suggests that we should classify narrative dislocation as a symptom of the uncertainty that characterises a change of era. In this case, the uncertainty takes the form of stories that raise questions about the sanity of their protagonists, the steady progress of science and technology, and the distinction between reality and fiction.

\subsection{Distrust of the creation of artificial life and technological progress as a cause of narrative instability}

In Black Mirror, we find especially obvious signs of an apprehension about the spread of technology that calls into question the notion of the endless progress of modern ideals founded on reason and science as agents of history. This perspective could be characterised as a response to the technological utopianism of scholars like Clay Shirky, ${ }^{37}$ who argues for the potentially positive effects of the Internet culture on the empowerment of individuals. The story lines of the series propose hypotheses whose plausibility depends on the conception of a near future in which technological development is superior to that of contemporary society, in which science has gained ascendancy over everyday life and human beings have the power to control nature and to replicate themselves. Both of these ideas can be found in the age-old Promethean and Faustian myths that imagine the creation of artificial life without divine permission, and the recreation of a living being out of the dead appears explicitly in Frankenstein (Mary Shelley, 1818) and its many retellings. The relevance of this theme has persisted into our era and has given rise to classics of science fiction like Blade Runner (1982) or Total Recall (1990; 2012), and in more recent films such as Ex Machina (2014) as well. Minority Report (2002) and Déjà Vu (2006) take hypothetical leaps to explore the ethics of public surveillance with the idea of access to visions of the future being used to support law enforcement activities. In these situations, not only do individual (or corporate, but private) ambitions come into play, but justice as a public objective and the State as its guarantor are drawn into the web, bringing things to a kind of crisis point. As the rise in surveillance studies demonstrates, the issue has become too complicated to be narrowed down, with so many different kinds of surveillance being carried out by agents as varied as big companies and governments, and individual Internet users. ${ }^{38}$ The use of new technologies for surveillance purposes can heighten awareness of risks but also generate a great deal of uncertainty. ${ }^{39}$ An illustrative example is the polysemous nature of the term "participatory surveillance", considered in a positive light, in the context of social networks where "the mutual, voluntary and horizontal nature of surveillance $[\ldots]$ ensures

\footnotetext{
${ }^{36}$ Kilbourn, Cinema, Memory, Modernity: The Representation of Memory from the Art Film to Transnational Cinema, 228.

${ }^{37}$ Shirky, Here Comes Everybody: The Power of Organizing without Organizations; Shirky, Cognitive Surplus : Creativity and Generosity in a Connected Age.

${ }^{38}$ Ball, Haggerty, and Lyon, Routledge Handbook of Surveillance Studies.

${ }^{39}$ Kroener and Neyland, "New Tecnologies, Security and Surveillance," 148.
} 
that users become empowered as they build their social relationships and their subjectivities." 40

But surveillance also has a darker side: for example, the concept of the "participatory panopticon", referring to "a transparent society constantly watched and recorded not by states and large corporations but by the citizens themselves", meaning that they reproduce "surveillance procedures historically linked to forms of police/state control" with the risk, furthermore, of being driven by impulses driven by voyeurism and spectacle..$^{41}$

Black Mirror openly explores the mistrustful side of the question. This terrifying risk is the central theme of the episode "Shut Up and Dance", where people who have been secretly watched are blackmailed under the threat of publishing embarrassing information about them online. The episode's teenage protagonist, Kevin (Alex Lawther), is warned that if he doesn't follow the anonymous orders he is given to perpetuate the blackmail chain, a video of him masturbating while looking at —or rather being looked at by - his computer will be made public. Another episode, "Arkangel” (\#4x02) deals with the question of the surveillance of children, with the story of a mother, Marie, who has a chip implanted in her daughter's brain in order to monitor her, check her health and see through her eyes. As an added feature, the Arkangel implant can pixelate any violent or disturbing images that might cause the child stress. Among other consequences of this technology, the child, Sara, is unable to detect obvious dangers around her. The idea of the Arkangel implant reflects what Valerie Steeve refers to as the complex interplay between children, parents and corporations in online spaces which illustrate

many of the tensions found in the emerging surveillance society. Parental surveillance purports to protect the child from unknown dangers, in keeping with both moral panics related to children and technology, and with the neoliberal trend to download responsibility to individual parents and children. In this sense, online parental surveillance is a form of both care and control. ${ }^{42}$ (Steeves 2012, 353)

The use of "invasive methods of surveillance" employed by the fictional mother, Marie (Rosemarie DeWitt) has the exact consequences described by Steeves, "diminish[ing] both the trust between parent and child and the child's ability to develop resiliency by encountering risks and learning from mistakes." 43 In the end, a teenage Sara (Brenna Harding), incapable of trusting Marie, abandons her after knocking her out in a rageful attack that is pixelated in her mind by the implant. Only when the surveillance technology is broken (by Sara herself) does she realise how badly she has beaten her mother.

\footnotetext{
${ }^{40}$ Bruno, "Surveillance and Participation on Web 2.0," 350.

${ }^{41}$ Ibid.

${ }^{42}$ Steeves, "Hide and Seek: Surveillance of Young People on the Internet," 353.

${ }^{43}$ Ibid., 359.
} 


\subsection{One more step towards the digitalization of subjectivity}

As noted above, a main feature of Black Mirror is the way that the uncertainty and distortion of reality experienced by the characters shapes the enunciative level of the series. As a result, the veracity of their memories, their view of the present and even their identity is constantly called into question. In the late twentieth and early twenty-first century, the latent conflict does not involve a deal with the devil or an attempt to play God, nor is there the tension between creator and creation that was still a key feature of Blade Runner. In this case, the Other responsible for concealing the truth is the neoliberal system that leads consumers to weave their own tangled webs. One of the most prized consumer goods offered by the fictitious corporations is the erasure of painful memories (resulting from a traumatic event such as a death, an accident, or a lost love) and the possibility of their replacement with artificial memories, which ultimately fail to serve. Paradoxically, while these kinds of mind-game films warn us of the risks of entrusting our memories to external agents, surveillance scholars suggest that the appropriation of digital data is "neither just a technical issue, nor an individual problem, but a societal problem", 44 where

economic actors such as corporations undertake surveillance and exercise violence in order to control certain behaviours, and in most cases people do not know that they are being surveilled. To guarantee production of surplus value and accumulate profit, corporations control economic behaviour of people and coerce them to produce or buy specific commodities. ${ }^{45}$

\section{Black Mirror as a case study}

As noted above, Black Mirror combines narrative complexity with the theme of the technological malaise of the "hypermodern era", along with other ideas like exacerbated individualism and consumerism. ${ }^{46}$ In the series, this malaise is inextricably linked to the misuse of the media, the entertainment industry and, in particular, the social networks hosted on mobile devices resulting from the exponential growth of digital technology.

This view is supported by recent studies that analyse Charlie Brooker's series from this perspective. ${ }^{47}$ It is no mere coincidence, argue Bender and Palmer ${ }^{48}$, that "the earliest digital manipulation of film is the cyborg vision in Westworld (Dir. Michael

\footnotetext{
${ }^{44}$ Allmer, "Critical Internet Surveillance Studies and Economic Surveillance," 140.

${ }^{45}$ Ibid., 141.

${ }^{46}$ Lipovetsky and Serroy, La Pantalla Global: Cultura Mediática y Cine En La Era Hipermoderna.

${ }^{47}$ Barraycoa and Martínez-Lucena, Black Mirror : Porvenir y Tecnología; García Marín and Aparici, iSonrie, Te Están Puntuando! : Narrativa Digital Interactiva En La Era de Black Mirror.

${ }^{48}$ Bender and Palmer, "The Digital Aesthetic of Violence: Introducing the Special Issue," 2.
} 
Crichton, 1973) as Yul Brynner's psychotic cowboy hunts for prey [...] [that] digitally manipulated images have their origin in images of violence." This acquires special relevance if we bear in mind that some Black Mirror episodes share with Westworld an uncertainty about the human or artificial nature of many apparently human characters. The series seems to evoke the idea of "hypermediation" 49 developed by Bolter and Grusin (1999), who calls attention to the chronic dissatisfaction suffered by the user due to the failure of the technology to offer an "authentic experience":

[a]lthough each medium promises to reform its predecessors by offering a more immediate or authentic experience, the promise of reform inevitably leads us to become aware of the new medium as a medium. Thus, immediacy leads to hypermediacy. The process of remediation makes us aware that all media are at one level a "play of signs". ${ }^{50}$

In the following section we will highlight some of the episodes of Black Mirror that fit best within the theoretical framework outlined here. ${ }^{6}$

\subsection{Memory turned into images and data: "The Entire Story of You” (\#1x03) and "Be Right Back” (\#2x01)}

"The Entire Story of You" depicts the contemporary obsession with documenting our life experience in images. In this episode, a device known as a "grain", inserted behind the ear of most of the characters in the story, stores everything that the individuals see, all of it recorded from their point of view. This audiovisual recording can be played back at will by the individual in question, with "rewind" and "zoom" functions. This grain allows them to review the vast stores of footage of their lives (filed by date, of course), either in their own eyes or projected onto an external surface. A POV sequence shot thus represents the conception of all past events. The "objective" record of this reality frees the camera-subjects from having to interpret their own memories - or those of othersor from assessing their life experience, given that the evidentiary value of the film image releases them from having to take a position in relation to any supposed truth: if it isn't recorded it doesn't exist, and if it is it speaks for itself without any need for reflection. Moreover, the surveillance element is also present in this episode thanks to the use of the grain by the police as a possible source of evidence or for the revision of a passenger's recent activity before they are permitted to board a flight.

The plot of this episode is constructed around the determination of Liam (Toby Kebbell), after a dinner with old friends of his wife, Ffion (Jodie Whittaker), to prove that she had an affair with one of them, Jonas (Tom Cullen). Progressively revealing a jealous, possessive and even violent personality that predisposes the spectator to view him as deluded and obsessive, Liam ends up gaining access to Jonas's and Ffion's grain images

\footnotetext{
${ }^{49}$ Bolter and Grusin, Remediation : Understanding New Media.

${ }^{50}$ Ibid., 19.
} 
by force, finally proving that Ffion did indeed sleep with Jonas when she was already in a relationship with Liam, just as he had suspected. Once he has visual evidence to support his suspicions, there is nothing left to discuss, no need to hear the reasons or the defence that his wife might proffer, because reality has the same status as the audiovisual sequence, which has provided the indisputable truth. The image not only establishes certainty but stands in place of that which it portrays. There is no need to consider Ffion's reasons or-assuming that monogamy is a basic moral value in the world of the story - the potentially mitigating circumstances of her husband's jealous behaviour and alcoholism. In this instance "the technological suppresses the affective." ${ }^{51}$ Devastated by the truth he longed to uncover, in the end Liam removes his own grain, a procedure that entails self-inflicted violence. Crushed over having lost Ffion and their daughter forever, Liam chooses to give up images and take control of the interpretation and recollection of his own past, which entails more than mere automatic viewing.

A comparison of this episode with an earlier exploration of the same theme, in the sci-fi thriller The Final Cut (2004), reveals the leap made by the collective imaginary from 2004 to 2011 in relation to the analogy between eye and camera ${ }^{52}$ established in both stories. In The Final Cut, upon when people fitted with memory implants die, the long POV shot documenting their lives is left in the hands of a professional editor, a stranger who edits the story of the deceased for subsequent public viewing, turning it into a heart-warming, "cleaned up" overview of their lives. Conversely, in Black Mirror, individuals can manage their own visual records and eliminate whatever they don't want to keep: the shameful moments, whatever they don't wish others to see or is too painful ever to watch again.

The non-equivalence between the audiovisual file of the past - the sound, the image, and the movement of the subject's gaze over it - and the truth of what that past represented for the subject who possesses it is reformulated once more in the episode " $\mathrm{Be}$ Right Back", in which the theme of storing images is combined with a reflection on the expression of opinions, feelings, tastes, etc., on social networks, as the platforms that host it all. In this episode, the information that people upload to the Internet over the course of their lives is depicted - in the first instance - as being so accurate and truthful that deceased individuals can effectively be recreated by compiling and processing their virtual behaviour. This offers the possibility of maintaining contact with the departed through their chat messages, speaking to them on the phone and even physically reproducing them in the form of a kind of inflatable dummy which, just by adding water, acquires the same volume, texture and shape as the person concerned (modelled on their photographs stored online) and "comes to life." Each of these possibilities arouses in Martha (Hayley Atwell) the desire to go a step further in the recovery of her deceased boyfriend, Ash (Domhall Gleeson): after exchanging written messages, she wants to hear his voice; after she hears it, she wants to touch him; once she has him by her side, she

\footnotetext{
${ }^{51}$ Garin, "No More Memories , La Mirada Distópica En Black Mirror,” 124.

${ }^{52}$ Vives-Ferrándiz Sánchez, “Todos Los Recuerdos Del Mundo: Ojo, Fotografía y Memoria En Black Mirror."
} 
wants to live with him. Of course, this is a service provided by a company that offers these products to grieving individuals.

The conversations offered by Ash's "replicant" are based on the messages that the real Ash posted on social networks when he was alive, and thus reflect his sense of humour, manner of expression, etc. However, Martha ultimately becomes profoundly dissatisfied with her late boyfriend's replica because there are things that the social networks do not know and therefore cannot apply to Ash's re-creation. The "double" proves incapable of preventing the mourning process, of fully reconstructing the absent person, because despite its obliging nature, it lacks thoughts, emotions, and a free will of its own. The image - in this case the identical but artificial body — of the lost loved one and the "public" nature of his behaviour are inadequate to the task of covering up the reality of his death, because the private and unpredictable qualities that made Ash a person cannot be programmed or re-created. In other words, it is precisely what the social networks don't know and cannot convert into data that Martha misses most. Nevertheless, she refuses to give up the android. Ash's double is kept locked up in the attic, constituting cold comfort and a sad remembrance of the real Ash; Martha can never fully accept it into her life, but at the same time she is unable to give it up completely due to its physical resemblance to Ash.

At one point, Martha asks the artificial Ash to kill himself by jumping from a cliff, and he unhesitatingly prepares to obey until she cries out that the real Ash would never have done it. Unlike Ash, the doubles in "White Christmas" (\#2x04) and "USS Callister" (\#4x01) are self-aware and suffer pain. Among other themes, the first of these two episodes explores the idea of digital "copies" created to make the lives of their "originals" easier, serving as personal secretaries. In the second episode, the doubles are avatars in a science fiction video game who find themselves at the mercy of one of their bosses in the real world, Robert Daly (Jesse Plemons). Daly uses his subordinates' doubles to get revenge for little things their "originals" have done that he took offence to. The selfawareness of the digital copies has the sole purpose of enabling Daly to punish them, although the "originals" have no knowledge of it and it has no consequences in the real world. Once again, alienation is expressed through an escape into a digital world.

\subsection{The justice spectacle and the lethal protection of the State: "White Bear" (\#2x02) and "Men Against Fire" (\#3x05)}

"White Bear" begins with a premise similar to that of mind-game films like Memento or The Bourne Identity: a woman wakes up with amnesia in a house where she finds photographs of herself, a young girl and a man, and where a strange logo appears on the TV screen. When she goes out to the street, everyone she meets films her and photographs her with their mobile phones, ignoring her pleas for them to stop. Further on, masked people with guns open fire on her. Two people she meets while fleeing explain to her that an electronic signal is responsible for the catatonic state of most of the population, who are interested only in recording everything on their mobiles. Their inactive condition allows the "hunters" to shoot, torture, and terrorise the citizens who 
are still unaffected by the signal that paralyses the rest. In the struggle to flee and to destroy the transmitter of the insidious signal that is supposedly the cause of the chaos in the streets, the protagonist gets hold of a gun and fires at an attacker in self-defence. But when she does, all that comes out of the barrel is confetti. The final twist in the story comes when the walls open to reveal a studio audience, which then breaks out in applause. It was all a reality show featuring the unwitting protagonist, Victoria (Leonora Crichlow), and which also constitutes her unusual sentence: the man in the photos was her late boyfriend, who kidnapped tortured and murdered the girl in the photos in a nearby forest (to which she had been led in the course of the reality show) while Victoria filmed his crimes on her mobile phone. Her punishment, handed down in a court ruling, consists of experiencing the same torture every day: waking up with no memory and suffering the terror of being an absolutely defenceless victim. In this way, the spectacularisation of justice involves the production of mass media content open to public participation: anyone is welcome to play the part of tormentor as an extra in the reality show, and to make free use of their mobile devices to record their own experience on the condition that they don't speak to the offender. This idea adds a whole new dimension to the "voyeuristic appeal of reality programs" 53 where "a person's moral value is no longer validated by the state or religion but through the public performance of their own value in a display of 'compulsory individuality' tuned to the needs of capital." 54

It is worth noting that a similar idea was on the base of The Running Man (Paul Michael Glaser,1987); however, in this film the convicted was wrongly accused, and he has the chance to escape public execution by surviving a reality show in which he is hunted by professional killers. Prison sentences thus veer dangerously away from the objective of law enforcement towards individually tailored castigation, as these "madeto-measure punishments" take over the personal lives of the offenders, who are deprived of their privacy.(6) We find something similar in the way that the confession of murder is obtained in the episode "White Christmas": by manipulating the conscience of the suspect and making his "digital double" tell his story for him. This is a representation of a crisis of the idea of justice as a universal ideal whereby all citizens are treated equally:

the State, having founded its raison d'être and its claim to citizens' obedience on the promise to protect its subjects against threats to their existence, but no longer able to deliver on its promise [...] is obliged to shift the emphasis of "fear protection" from dangers to social security to the dangers to personal safety. ${ }^{55}$

The premise of "White Bear" also raises the question of the extent to which someone whose memories have been erased can be considered guilty of her crimes, and

\footnotetext{
${ }^{53}$ Baruh, "Publicized Intimacies on Reality Television: An Analysis of Voyeuristic Content and Its Contribution to the Appeal of Reality Programming," 2009.

${ }^{54}$ Skeggs and Wood, Reacting to Reality Television. Performance, Audience and Value, 217.

${ }^{55}$ Bauman, Miedo Líquido: La Sociedad Contemporánea y Sus Temores.
} 
whether the application of the popular maxim "an eye for an eye" might be turned into a vehicle of enjoyment for others who can watch it all as a spectacle that pushes the punishment to outrageous extremes. In a sense, then, this episode points to the risks entailed in applying the manipulation and study of the human mind to the administration of justice - an issue that is not entirely unrelated to neuroethics - in view of the increasingly radicalised brutality of television in its aim to profit out of revelling in another's pain, engaging a spectator who doesn't merely watch as an outsider but also enters into the spectacle of collective derision.

The crisis of confidence in the State, suspected of manipulating the members of its military to make them more destructive, has been depicted in acclaimed films like The Manchurian Candidate and Jacob's Ladder. The narratives of these films explore the confusion of the troubled and traumatised minds of these soldiers, who are victims of the unscrupulous trickery of the political elite. The exploration of this issue in the Black Mirror episode "Men Against Fire" is not revealed as such until the end, since for most of the story all we see is a kind of apocalyptic future in which groups of soldiers like Stripe (Malachi Kirby) are dedicated to protecting the population by exterminating aggressive mutants known as "roaches", whom they are able to perceive with a heightened awareness thanks to brain implants. However, Stripe's exposure to a LED device that appears to deactivate the effect of the implant allows him to discover that the "roaches" are actually humans whose appearance is distorted by the effect of the device, making them look like monsters in the soldiers' eyes. The ultimate objective of the deceit is to enable the soldiers, who believe they are exterminating monsters, to carry out genocide without suffering problems of conscience. The restriction of the point of view to Stripe's altered perception aligns our perspective with that of the executioners, especially when in another plot twist it is revealed that he voluntarily agreed to participate in the genocide, and to the erasure of his memory and the modification of his perception of reality. In this way, one of the most horrifying spectres of twentieth-century history is reformulated through a narrative experiment that invokes the influence of technological development. The episode concludes with a sad ending in which Stripe, threatened by his military leaders with being forced to watch himself killing defenceless humans on a video loop, agrees to have his memory erased again. After he is discharged, he is decorated with medals of honour and made to believe he is living in a perfect home with the ideal wife, when in reality he is all alone in a dilapidated building.

These are thus narrative approaches that begin with restricting the narration (without providing any obvious signs of the restriction) to the experience of characters whose perception of the diegetic reality is misleading — both to the characters themselves and to the spectator who shares their skewed perspective. In this way, these characters become the bearers of an "unreliable narration" 56 that renders the spectator unable to determine who holds information on the story or whether that information is accurate. It is in this sense - narratively speaking - that Black Mirror reflects a part of the complexity

\footnotetext{
${ }^{56}$ Ferenz, "Fight Clubs, American Psychos and Mementos. The Scope of Unreliable Narration in Film."
} 
described by Mittell, and Buckland in their definitions of puzzle films, with their blurring of the lines between the different levels of reality, and their unstable or amnesiac characters.

\subsection{Entertainment that refuses to die: "San Junipero" (\#3x04)}

Black Mirror offers one exception to the pessimism that typifies the series and its apprehensions in relation to the creation of virtual worlds and the mediation of technology between an individual's consciousness and the real world. This exception is the episode "San Junipero", which once again expresses the existential dread of death through a nonlinear narrative. San Junipero is the name of a town inhabited mainly by young people who apparently meet there week after week to enjoy its abundant partying options in a kind of perpetual holiday setting. In this resort town where everyone is young and dressed in 1980s fashions, two women meet: Kelly (Gugu Mbatha-Raw) and Yorkie (Mackenzie Davis). Kelly, an uninhibited veteran of San Junipero, tries to seduce Yorkie, a shy virgin who is new to the place, and who turns down her proposition. The next week, however, she goes back to the same discotheque to look for Kelly, and the two spend the night together. After an ellipsis in which the spectator assumes that the two young women have been apart, we find one of the first cases of non-linearity and subsequently we understand that San Junipero is a virtual world parallel to the external reality of the characters' "real" bodies. "Outside", Kelly is a woman who has been diagnosed with an illness and has only a few months to live. Her husband's decision "not to stay" refers to the fact that when he knew he was dying, he refused to leave his consciousness living on forever in San Junipero. When Kelly visits Yorkie (both as old women in external reality), we learn that the latter has been bedridden since she was young, when she had a car accident after her parents' negative reaction to her confession that she was a lesbian. San Junipero is a place populated by people who are either sedated or already deceased, who have travelled there mentally, either "on trial" (temporarily, to decide whether they want to purchase the "transfer" of their minds after death), or "definitively" after dying, when they can also decide to "leave" whenever they want, dying not only physically (their bodies are already buried) but also mentally. The main features of puzzle and mind-game films, such as a non-linear narrative and a fragmented spatiotemporal reality, are crucial to the design of San Junipero's diegetic universe.

The episode ends with a number of melodramatic turns: a scene that aesthetically and musically recalls the levity of an indie music video uses parallel editing to cut back and forth between Yorkie's life in San Junipero and Kelly's death and the lowering of her coffin into the grave. Just when the spectator has assumed that Kelly is forever gone, her young self appears in San Junipero to stay with Yorkie. Technology thus turns into an ally against death, offering the possibility of eternal life in a resort town where there is no place for grieving. Despite its artificial and frivolous nature, San Junipero offers a space and time where the relationship between the two women has some kind of future, and where the death that awaited them in the "real" world cannot touch them. When earlier episodes of the series explored attempts to overcome death through technology, such as in "Be Right Back", the results were disastrous. But in this episode, the soundtrack, the mise-en-scène and even the wedding as an important part of the narrative 
closure point to a very different direction. Any possibility of a critique of the alienation resulting from excessive technology is underplayed by the aesthetic of the happy ending.

"San Junipero" has an obvious precursor in the film Open Your Eyes and its remake Vanilla Sky, as both the films and the episode are essentially stories about prolonging life beyond death, in the case of the films by keeping the unconscious or dead body cryogenically frozen and manipulating the consciousness so that-without disconnecting it from the materiality of the body-the individual concerned can experience a life that they themselves designed without being reminded of its artificial nature. This constitutes a clear affirmation of the Cartesian notion linking identity and existence to consciousness. The main difference is that while in the films the imaginary world fails because the subconscious retains its traumas, in "San Junipero" nothing appears to stand in the way of its success.

\section{Conclusions: cracked screens for broken gazes}

Black Mirror interweaves a kind of narration particularly characteristic of the last decades with plots that express certain key themes of our age, such as disillusion with politics, the surveillance role of new technologies, or the bitter harshness of reality TV. In the series' distinctive approach to the science fiction genre we have identified some contemporary issues expressed in fiction form. This is the mission historically attributed to the science fiction genre and Black Mirror offers an innovative twist in this respect by incorporating the complex narrative approach of the mind-game film into an anthology series format. In future research we hope to explore each episode in more detail in order to analyse the development of the narrative and aesthetic resources of the mind-game film in this series.

The menace lurking behind the widespread use of fashionable devices in Black Mirror is not based merely on a conservative or moralistic fear of technological development. The protagonists of "San Junipero" are aware of when they are in the parallel world and when they are back in reality. While most episodes explore the ill-fated consequences of the unrestrained use of new technologies to control memories, regulate personal relationships or reduce all human experience to data, the dialogues in this episode ponder the moral dilemma posed by the choice of a fictitious life. In a way, the "happy ending" in "San Junipero" rewards the thoughtful deliberation of its characters.

On the other hand, when the characters abandon their own subjectivity and delegate the responsibility for interpreting the world entirely to technology, something breaks down. Just like the glass in the opening credits that cracks after the rapid changes to the digital characters that form the series' main title shot, the wild, unstructured narrative takes on tragic hues. According to Paul Virilio, art "never just sleeps in front of new technologies, but deforms them and transforms them" 57 to mutually adapt (and adapt them) to our cultural needs. And this is where the playful challenge that can be a feature of mind-game films and complex television takes over, through the perspective of distorted subjectivities, to launch a scathing critique on the grotesque extremes that can

\footnotetext{
${ }^{57}$ Virilio and Armitage, Virilio Live : Selected Interviews, 159.
} 
result from replacing the human gaze with the tantalizing frame of technology, and the imperfect human memory with the inexhaustible capacity of its artificial counterpart.

\section{Endnotes}

1. The vast majority of the literature on the question locates the rise of fractured film narratives in the 1990s.

2. There is a general consensus among different scholars that post-classical cinema followed on from the European modern cinema movement that had its climax in the 1960s. We are particularly interested in the conception of post-classical cinema that highlights its interest in visual spectacle, sometimes at the expense of the film's narrative dimension, ${ }^{58}$ and in self-reference. This is not to say that post-classical cinema rejects the legacy of classical resources; quite to the contrary, many of the key features of classicism are present in post-classical cinema, and thus "post-classical" does not necessarily have to mean "anti-classical". 59

3. "The National Anthem" (\#1x01), and "The Waldo Moment" (\#2x03) are quite explicit on this point. In both episodes the political space in the media privileges sensationalism, scathing critiques and the humiliation of politicians on television. In this way, the absence of serious and critical debate drags politics into the realm of the reality TV show. Wodak and Forchtner explain how the media's "recent preoccupation with the cult of celebrity has led to interest in the private lives of politicians" (Talbot, 2007). Thus, private lives are perceived [as] newsworthy and scandalised." 60 In turn, they analyse increasingly successful TV series dealing with politics and the action of politicians, such as The West Wing or House of Cards. According to these authors, these series "provide an apparent window into the 'realities behind politics' and construct a proximity that allows viewers to relate more closely to politics and politicians."

4. For an examination of the specific resources developed by post-classical cinema in relation to fractured narratives, see Palao-Errando, Loriguillo-López, and SorollaRomero. ${ }^{61}$

5. For a more detailed reflection on the influence of technology in puzzle films, see Jan Simons. ${ }^{62}$

6. For a detailed analysis of the episode, see Cigüela and Martínez Lucena. ${ }^{63}$

${ }^{58}$ Thanouli, Post-Classical Cinema : An International Poetics of Film Narration; Company and Marzal Felici, La Mirada Cautiva : Formas de Ver En El Cine Contemporáneo.

${ }^{59}$ Bordwell, "Film Futures."

${ }^{60}$ Wodak and Forchtner, "The fictionalisation of politics", in The Routledge Handbook of Language and Politics, ed. Ruth Wodak and Bernhard Forchtner (Routledge: London; New York, 2018), 572-86.

${ }^{61}$ Palao-Errando, Loriguillo-López, and Sorolla-Romero, "Beyond the Screen, Beyond the Story: The Rhetorical Battery of Post-Classical Films."

${ }^{62}$ Simons, "Complex Narratives," 2014.

${ }^{63}$ Cigüela Solá and Martínez Lucena, "Screen Technologies and the Imaginary of Punishment: A Reading of Black Mirror's 'White Bear.'” 


\section{References}

Allmer, Thomas. "Critical Internet Surveillance Studies and Economic Surveillance." In Internet and Surveillance: The Challenges of Erb 2.0 and Social Media, edited by Christian Fuchs, Kees Boersma, Anders Albrechtslund, and Marisol Sandoval, 12445. New York: Routledge, 2012.

Ball, Kirstie, Kevin D. Haggerty, and David Lyon. Routledge Handbook of Surveillance Studies. Abingdon, Oxon : Routledge, 2012.

Barraycoa, Javier., and Jorge. Martínez-Lucena. Black Mirror : Porvenir y Tecnología. Barcelona : UOC, 2017.

Baruh, Lemi. "Publicized Intimacies on Reality Television: An Analysis of Voyeuristic Content and Its Contribution to the Appeal of Reality Programming." Journal of Broadcasting \& Electronic Media 53, no. 2 (2009): 190-210.

Bauman, Zygmunt. Miedo Líquido: La Sociedad Contemporánea y Sus Temores. Barcelona : Paidós, 2007.

Bender, Stuart, and Lorrie Palmer. "The Digital Aesthetic of Violence: Introducing the Special Issue." Journal of Popular Film and Television 45, no. 1 (2017): 2-3. https://doi.org/10.1080/01956051.2017.1270133.

Bolewski, Christin. "Nonlinear Narratives: Crossing Borders between Contemporary Film, Art and Digital Media Practice." International Journal of the Arts in Society 6, no. 1 (2011): 239-50.

Bolter, J. David, and Richard. Grusin. Remediation: Understanding New Media. Cambridge, Mass. : MIT Press, 1999.

Bordwell, David. "Film Futures." SubStance 31, no. 1 (2002): 88-104. https://doi.org/10.1353/sub.2002.0004.

Branigan, Edward. "Nearly True : Plots, Forking Forking Interpretations." SubStance 31, no. 97 (2002): 105-14.

Brooker, M. Keith. Science Fiction Television: A History. Westport, CT: Praeger, 2004.

Bruno, Fernanda. "Surveillance and Participation on Web 2.0." In Routledge Handbook of Surveillance Studies, edited by Kirstie Ball, Kevin D. Haggerty, and David Lyon, 343-51. Abingdon, Oxon: Routledge, 2012.

Buckland, Warren. Hollywood Puzzle Films. New York; London: Routledge, 2014.

—. Puzzle Films : Complex Storytelling in Contemporary Cinema. Malden, MA : 
Wiley-Blackwell, 2009.

Burch, Noël. El Tragaluz Del Infinito : Contribución a La Geneaología Del Lenguaje Cinematográfico. Madrid : Cátedra, 1987.

Cameron, Allan. Modular Narratives in Contemporary Cinema. New York: Palgrave Macmillan, 2008.

Català Domènech, Josep M. “El Tiempo Visible.” Líbero 15, no. 30 (2012): 33-46.

Cigüela Solá, Javier, and Jorge Martínez Lucena. "Screen Technologies and the Imaginary of Punishment: A Reading of Black Mirror's 'White Bear."' Empedocles: European Journal for the Philosophy of Communication 7, no. 1 (2016).

Company, Juan Miguel., and José Javier Marzal Felici. La Mirada Cautiva : Formas de Ver En El Cine Contemporáneo. [Valencia] : Generalitat Valenciana, 1999.

Cubitt, Sean. The Cinema Effect. Massachussets : MIT Press, 2005.

Daly, Kirsten. "Cinema 3.0: The Interactive-Image." Cinema Journal 1, no. 50 (2010): 81-98.

Doane, Mary Ann. The Emergence of Cinematic Time: Modernity, Contingency, the Archive. Cambridge (Mass.) : Harvard University Press, 2002.

Dzialo, Chris. "“Frustrated Time' Narration: The Screenplays of Charlie Kaufman." In Puzzle Films. Complex Storytelling in Contemporary Cinema, edited by Warren Buckland, 107-28. Chichester, West Sussex, U.K: Wiley-Blackwell, 2009.

Elsaesser, Thomas. "Los Actos Tienen Consecuencias. Lógicas Del Mind-Game Film En La Trilogía de Los Ángeles de David Lynch." L'Atalante. Revista de Estudios Cinematográficos 15 (2013): 7-18.

. "The Mind-Game Film." In Puzzle Films. Complex Storytelling in Contemporary Cinema, edited by Warren Buckland, 13-41. Chichester, West Sussex, U.K: WileyBlackwell, 2009.

Ferenz, Volker. "Fight Clubs, American Psychos and Mementos. The Scope of Unreliable Narration in Film." New Review of Film and Television Studies 3, no. 2 (2005): 13359.

García Marín, David., and Roberto. Aparici. ¡Sonríe, Te Están Puntuando! : Narrativa Digital Interactiva En La Era de Black Mirror. Barcelona : Gedisa, 2017.

Garin, Manuel. "No More Memories, La Mirada Distópica En Black Mirror.” In Black Mirror. Porvenir y Tecnología, edited by Jorge Martínez Lucena and Javier Barraycoa, 115-26, 2017. 
Hill, Rodney. "Anthology Drama: Mapping The Twilight Zone's Cultural and Mythological Terrain." In The Essential Science Fiction Television Reader, edited by J.P. Telotte, 111-26. Lexinton: The University Press of Kentucky, 2008.

Kilbourn, Russell J. A. Cinema, Memory, Modernity: The Representation of Memory from the Art Film to Transnational Cinema. London : Routledge, 2010.

Kroener, Inga, and Daniel Neyland. "New Tecnologies, Security and Surveillance." In Routledge Handbook of Surveillance Studies, edited by Kirstie Ball, Kevin D. Haggerty, and David Lyon, 141-48. Abingdon, Oxon: Routledge, 2012.

Lipovetsky, Gilles, and Jean. Serroy. La Pantalla Global : Cultura Mediática y Cine En La Era Hipermoderna. Barcelona : Editorial Anagrama, 2009.

Lister, Martin. New Media : A Critical Introduction. 2nd ed. London [etc.] : Routledge, 2009.

Lury, Celia. Prosthetic Culture: Photography, Memory and Identity. London: Routledge, 1998.

Manovich, Lev. El Lenguaje de Los Nuevos Medios de Comunicación : La Imagen En La Era Digital. Barcelona [etc.] : Paidós Ibérica, 2005.

Michaud, Philippe-Alain. Aby Warburg and the Image in Motion. New York: Zone Books, 2004.

Mittell, Jason. Complex TV: The Poetics of Contemporary Television Storytelling. New York : New York University Press, 2015.

_. "Narrative Complexity in Contemporary American Television." The Velvet Light Trap, no. 58 (2006): 29-40.

- "Sites of Participation: Wiki Fandom and the Case of Lostpedia." Transformative Works and Cultures 3 (2009).

Palao-Errando, José Antonio, Antonio Loriguillo-López, and Teresa Sorolla-Romero. "Beyond the Screen, Beyond the Story: The Rhetorical Battery of Post-Classical Films." Quarterly Review of Film and Video 9208 (2018): 1-22. https://doi.org/10.1080/10509208.2017.1409097.

Parks, Lisa. "Flexible Microcasting: Gender, Generation, and Television-Internet Convergence." In Television after TV: Essays on a Medium in Transition, edited by Lynn Spigel and Jan Olson, 133-56. Durham, NC: Duke University Press, 2004.

Shirky, Clay. Cognitive Surplus: Creativity and Generosity in a Connected Age. London : : Penguin, , 2011. 
Here Comes Everybody: The Power of Organizing without Organizations. New York : Penguin Press, 2008.

Simons, Jan. "Complex Narratives." New Review of Film and Television Studies 6, no. 2 (2008): 111-26. https://doi.org/10.1080/17400300802098263.

. "Complex Narratives.” In Hollywood Puzzle Films, edited by Warren Buckland, 17-34. New York; London: Routledge, 2014.

Skeggs, Beverley, and Helen Wood. Reacting to Reality Television. Performance, Audience and Value. London, New York: Routledge Taylor \& Francis Group, 2012.

Steeves, Valerie. "Hide and Seek: Surveillance of Young People on the Internet." In Routledge Handbook of Surveillance Studies, edited by Kirstie Ball, Kevin D. Haggerty, and David Lyon, 352-60. Abingdon, Oxon: Routledge, 2012.

Sutton, Damian. Photography Cinema, Memory: The Crystal Image of Time. Minneapolis: The University of Minnesota Press, 2009.

Tellote, J.P. "Lost in Space: Television as Science Fiction Icon.” In The Essential Science Fiction Television Reader, edited by J.P. Telotte, 37-54. Lexinton: The University Press of Kentucky, 2008.

Thanouli, Eleftheria. Post-Classical Cinema: An International Poetics of Film Narration. New York: Wallflower Press, 2009.

Tryon, Charles. "TV Time Lords: Fan Cultures, Narrative Complexity, and the Future of Science Fiction Television." In The Essential Science Fiction Television Reader, edited by J.P. Telotte, 301-14. Lexinton: The University Press of Kentucky, 2008.

Virilio, Paul., and John Armitage. Virilio Live: Selected Interviews. London [etc.]: SAGE, 2001.

Vives-Ferrándiz Sánchez, Luis. "Todos Los Recuerdos Del Mundo: Ojo, Fotografía y Memoria En Black Mirror.” Revista Sans Soleil. Estudios de La Imagen 10 (2018).

Wodak, Ruth and Forchtner, Bernhard. The Routledge Handbook of Language and Politics. Routledge: London; New York, 2018.

Young, Paul. The Cinema Dreams Its Rivals : Media Fantasy Films from Radio to the Internet. Minneapolis : University of Minnesota Press, 2006.

Zavala, Lauro. "Para Analizar La Metaficción En Cine." In Imágenes Conscientes: AutoRepresentacioneS 2, edited by Marta Álvarez, 73-86. Binges : Orbius Tertius, 2013. 
